\title{
СТРУКТУРНО-ДИНАМІЧНА МОДЕЛЬ РОЗВИТКУ ЕМПАТІЇ ПРАКТИЧНИХ ПСИХОЛОГІВ
}

\begin{abstract}
Котлова Л.О., кандидат психологічних наук, дочент, доиент кафедри соиіальної та практичної психології, Житомирський державний університет імені Івана Франка м.Житомир, Україна, ORCID ID: https://orcid.org/0000-0003-2994-6724
\end{abstract}

Шикирава Н.М., аспірантка кафедри сочіальної та практичної психологї̈, Житомирський державний університет імені Івана Франка, м.Житомир, Украйна,

ORCID ID: https://orcid.org/0000-0002-8903-1027

DOI: https://doi.org/10.31435/rsglobal_conf/25122020/7311

\begin{abstract}
The article is devoted to the problem of empathy in the context of professional activity of practical psychologists. Empathy is considered as an integrative quality of personality. Personality empathy is a dynamic phenomenon that has a complex hierarchical structure. Hierarchical relations between the components of this phenomenon determine its internal dynamics. Empathy as a dynamic phenomenon is manifested on the affective, cognitive, conative, subjective and ideological levels. Affective, cognitive and conative components represent its procedurality as a psychological phenomenon. Their systematic interaction in combination with other subjective characteristics of the specialist represents a subjective component and the synergetic level of empathy development together with an active life position - worldview. According to the levels of empathy development, the following types are distinguished: affective or physiological, modeling, constructive, personal-semantic, transfinite. In the basis of the level of phenomenon manifestation there are the corresponding mechanisms: emotional contagion, identification, personal reflection, reflection (personal, moral, social), anticipation, decentration.
\end{abstract}

Keywords: structural-dynamic model, development of empathy, professional qualities, empathic process, professional activity.

Вступ. Розвинена емпатія - це ключовий фактор успішного професійного становлення в багатьох видах діяльності. Особливого значення набувають розвинені емпатійні здібності в професійній діяльності практичного психолога.

Аналіз досліджень (Л.Журавльова [8], К.Роджерс [23], Ю.Орлов [15]) дає нам можливість стверджувати, що емпатія посідає одне 3 найважливіших місць у структурі професійних якостей практичних психологів. Вміння приєднатися до клієнта, подивитися на проблему і ситуацію ніби зсередини, «очима клієнта» $\epsilon$ необхідною професійною якістю психолога-консультанта [6]. Здатність до емпатії, як вміння проникати та приймати світ іншої людини (Л.Мова [14], Н.Пов'якель [17], Є.Романова [18], Н.Сургунд [20]) є беззаперечним критерієм успішності консультативного процесу. Більшість дослідників вважають розвинену емпатію однією з визначальних умов успішного професіогенезу практичних психологів.

Дослідження емпатії в рамках психотерапії найбільш широко представлено в роботах К. Роджерса [23], який визначав емпатію як тимчасове життя іншим життям, делікатне перебування в ньому без оцінювання та осуду. Дуже важливим у розвитку теорії емпатії, на наш погляд, було виділення науковцем трьох принципових особливостей емпатійного процесу. По-перше, дослідник вперше вказав на емпатійне розуміння як важливу умову розвитку особистості у процесі взаємодії між терапевтом та клієнтом. Він же стверджував, що вмілий терапевт відчуває світ клієнта, як свій власний, не втрачаючи якості «ніби то», і втрачаючи цю якість, ми маємо справу з ідентифікацією і терапевт не може об'єктивно розуміти клієнта. Т. Мері, послідовник К. Роджерса, зауважував, що саме завдяки емпатії психотерапевт може ввійти в емоційний світ іншої людини так, ніби то він і $є$ тією людиною, не втрачаючи якості «ніби то» [22]. По-друге, наявність в емпатії співпереживання, безумовного прийняття будьяких переживань об'єкта, а не просто позитивного ставлення, симпатизування об'єкту. Потретє, емпатійний процес - це процес динамічний, а не статистичний, який залежить і від професійної підготовки терапевта і від готовності, зрілості клієнта. О.Орлов та М.Хазанова [15] визначають емпатію як процес безоціночного співпереживання терапевта реальним i актуальним переживанням клієнта, наполягаючи на невтручанні в процес усвідомлення своїх почуттів того, кому емпатують. «Безоціночність - одна 3 цілей на шляху змін клієнтом свого ставлення до себе, і консультант повинен представляти собою еталон даної позиції» [6, с.71]. 
Багато дослідників вказують на те, що психотерапевт, проникаючи в світ клієнта, повинен турбуватися про те, щоб клієнт не проникав в його світ. Тобто, психолог, будуючи емпатійний контакт 3 клієнтом, може відкривати свій особистий життєвий досвід, при цьому чітко усвідомлюючи, для чого він це робить. Терапевт не повинен розкривати себе повністю в емпатійному процесі, він просто знижує поріг захисту, щоб сприйняти клієнта, намагаючись при цьому не допустити його в свою емоційну сферу. Такими чином, емпатія розуміється дослідниками як захисна функція терапевта, для якого клієнт $\epsilon$ чужим, зовнішнім по відношенні до нього, але в той же час необхідним для вияву своєї сутності.

У терапевтично-клієнтських взаєминах емпатійний стосунок $\epsilon$ найважливішим компонентом. Зміст емпатійного стосунку прямо залежить від психологічної зрілості психотерапевта. Зрілий терапевт пропонує ту форму емпатії, яка зрозуміла і підтримується клієнтом, натомість молоді психотерапевти демонструють клієнту свою улюблену форму емпатії.

Трактуючи явище емпатії з психотерапевтичної точки зору, спираючись на висновки багатьох дослідників про існування співчуття та співпереживання як форм емпатії, можна вважати, що при співпереживанні, яке передбачає переживання почуттів клієнта як своїх власних, психотерапевт співвідносить свій досвід 3 досвідом клієнта, в окремих випадках обмірковує шляхи попередження такого розгортання подій у власному житті. При співчутті психотерапевт переживає 3 приводу почуттів клієнта, не ідентифікуючи їх 3 собою та власним досвідом. Звичайно, співчуття та співпереживання рідко проявляються в «чистому» вигляді, як правило під час переживання співчуття може проявлятися співпереживання, а під час співпереживання співчуття. Проте можна констатувати, що одна з форм емпатії все таки $є$ домінуючою.

Мета статті: на основі теоретичного обгрунтування сутності емпатії представити структурно-динамічну модель іiі розвитку у практичних психологів, розкрити всі їі структурні компоненти.

Методи дослідження. 3 метою вивчення підходів щодо розуміння сутності процесу емпатії особистості було використано такі методи як: аналіз психологічної літератури 3 проблеми дослідження; порівняння, класифікація, систематизація й узагальнення теоретичних та емпіричних даних для побудови та розкриття сутності структурно-динамічної моделі розвитку емпатії к психологів.

Результати дослідження. В аспекті вивчення емпатії як ключової професійної якості практичного психолога важливо окреслити основні підходи до періодизації професійного становлення фахівців. Варто зазначити, що це завдання виявилось нелегким, оскільки більшість дослідників виходять 3 різних засад, доповнюють один одного, окреслюють різні етапи професіогенезу. Найчастіше науковці подають опис етапів становлення фахівців, розпочинаючи 3 моменту професійного самовизначення, в означеннях якого відсутня одностайність:

- «Оптант» - стадія підготовки до життя, до праці, свідомого і відповідального планування і вибору професійного шляху. Оптація - це не стільки вказівка на вік, скільки на ситуацію вибору професії (Є. Климов) [10];

- «Аморфна оптація» - професійна орієнтовані інтереси і схильності; «Оптація» професійні наміри, вибір шляху професійної освіти i професійної підготовки, учбовопрофесійне самовизначення (Е. Зєєр) [9];

- допрофесійного розвитку; пошуку і вибору професії (Ю. Поваренков) [16];

- професійне самовизначення; вибір професії (В. Гупаловська) [7].

По-різному дослідники називають етап безпосередньої підготовки до професії:

- «адепт» - стадія професійної підготовки (Є. Климов) [10];

- професійна підготовка (Е. Зєєр) [9];

- професійного навчання (Ю. Поваренков) [16];

- професійна освіта (В. Гупаловська) [7].

Найбільш різні трактування дослідників отримав етап входження в професію, професійного розвитку:

- «адаптант» - стадія входження в професію після завершення професійного навчання; «інтернал» - стадія входження в професію як повноцінного колеги, здатного стабільно працювати на нормальному рівні (С. Климов) [10];

- професійна адаптація - освоєння нової соціальної ролі, досвіду самостійного виконання професійної діяльності, професійно важливі якості; первинна професіоналізація професійна позиція, інтегративні професійно значимі констеляції, індивідуальний стиль діяльності, кваліфікована праця (Е. Зєєр) [9]; 
- самостійної професійної діяльності (Ю. Поваренков) [16];

- професійний розвиток: професійна адаптація; апробація теоретичних знань у практичній діяльності; професійне самовдосконалення, підвищення кваліфікації (В. Гупаловська) [7];

- адаптація до професії; самоактуалізація в професії - пристосування людини до професії; гармонізація 3 професією - людина легко виконує завдання за засвоєними технологіями, працює як би «граючи» (А. Маркова) [13];

Різні погляди існують щодо назви та трактування і етапу майстерності у професії:

- «майстер» - стадія, коли працівник помітно виділяється на загальному тлі; «авторитет» - стадія, яка означає, що працівник став «кращим серед майстрів»; «наставник»стадія, яка характеризує вищий рівень роботи будь-якого фахівця; працівник, здатний передати кращий свій досвід (С.Климов) [10];

- вторинна професіоналізація - професійний менталітет, ідентифікація з професійним співтовариством, професійна мобільність, корпоративність, гнучкий стиль діяльності, висококваліфікована діяльність; професійна майстерність - творча професійна діяльність, рухливі інтегративні психологічні новотвори, самопроектування своєї діяльності і кар'єри, вершина (акме) професійного розвитку (Е.Зєєр) [9];

- післяпрофесійного розвитку (Ю. Поваренков) [16];

- професійне становлення: підвищення рівня професіоналізму, набуття професійного авторитету, досягнення активності, самостійності, творчого підходу у професійній діяльності (В.Гупаловська) [7];

- етап творчого самовизначення себе як особистості - прагнення реалізувати свою головну життєву ідею (А. Маркова) [13];

Аналіз робіт дослідників свідчить про те, що більшість 3 них обстоювали конструктивний та прогресивний тип розвитку професійного становлення.

Аналіз досліджень особливостей професійного становлення практичних психологів (Т. Вілюжаніна [4], Л. Мова [14], Н. Сургунд [20], Н. Повякель [17]) вказує, що більшість науковців досліджували етап підготовки до професійного життя, студентський період. Натомість модель діяльності практичного психолога, його важливі професійні якості розпочинаючи 3 періоду адаптації до професійного розквіту, характеристики його професіоналізму недостатньо вивчені.

Ретроспективний аналіз дефініцій емпатії, опису іï феноменології, структури та проявів дає можливість виділити декілька змістовно-категоріальних груп ії тезаурусу та складових елементів:

- світоглядний компонент: активна життєва позиція (А. Маслоу) [12], творче ставлення до життя, прагнення до саморозвитку, досконалості та зрілості (М. Бердяєв) [2], самоефективність (А. Бандура) [1];

- суб'єктний компонент: реалізація его-станів «Дорослий - Дорослий» (Е. Берн) [3], вроджені потреби в зростанні та розвитку (Е. Берн [3], А. Маслоу [12], К. Роджерс) [23], психологічна свобода та довіра до себе (М. Бердяєв) [2], відповідальність, впевненість у собі, творча лабільність (А. Бандура) [1];

- конативний компонент: повага до інших, здатність до саморегуляції (С. Степанов) [19];

- когнітивний компонент: здатність до антиципації (А. Бандура) [1], здатність до рефлексії, аналізу власних дій та вчинків (С. А. Степанов) [19];

- афективний компонент: стриманість, відкритість (М. Бердяєв) [2].

Узагальнення теоретичних положень наведених вище досліджень дозволило нам дійти висновку щодо наявності симптомокомплексу (системи) особистісних та соціальнопсихологічних характеристик, що описують емпатійну особистість, необхідності розгляду емпатійності як складноструктурованої інтегративної особистісної якості та теоретично обгрунтувати структурно-динамічну модель іï розвитку. Емпатія розглядається нами як інтегративна властивість особистості. Емпатія особистості є динамічним феноменом, який має складну ієрархічну структуру. Ієрархічні відносини між складовими цього феномену обумовлюють іiї внутрішню динаміку (рис.1).

Емпатія як динамічний феномен проявляється на афективному, когнітивному, конативному, суб'єктному та світоглядному рівнях (рис.1).

Афективний, когнітивний та конативний компоненти репрезентують іiі процесуальність як психологічного феномена. Їх системна взаємодія в поєднанні 3 іншими суб'єктними характеристиками фахівця репрезентує суб'єктний компонент, а синергетичний рівень розвитку емпатії разом з активною життєвою позицією - світоглядний. Відповідно до рівнів розвитку емпатії виділяються іiі типи: афективна або фізіологічна, моделююча, конструктивна, особистісно-смислова, трансфінітна. В основі функціонування кожного з рівнів прояву феномену 
лежать відповідні механізми: емоційне зараження, ідентифікація, особистісна рефлексія, рефлексія (особистісна, моральна, соціальна), антиципація, децентрація, моральна трансфінітна.

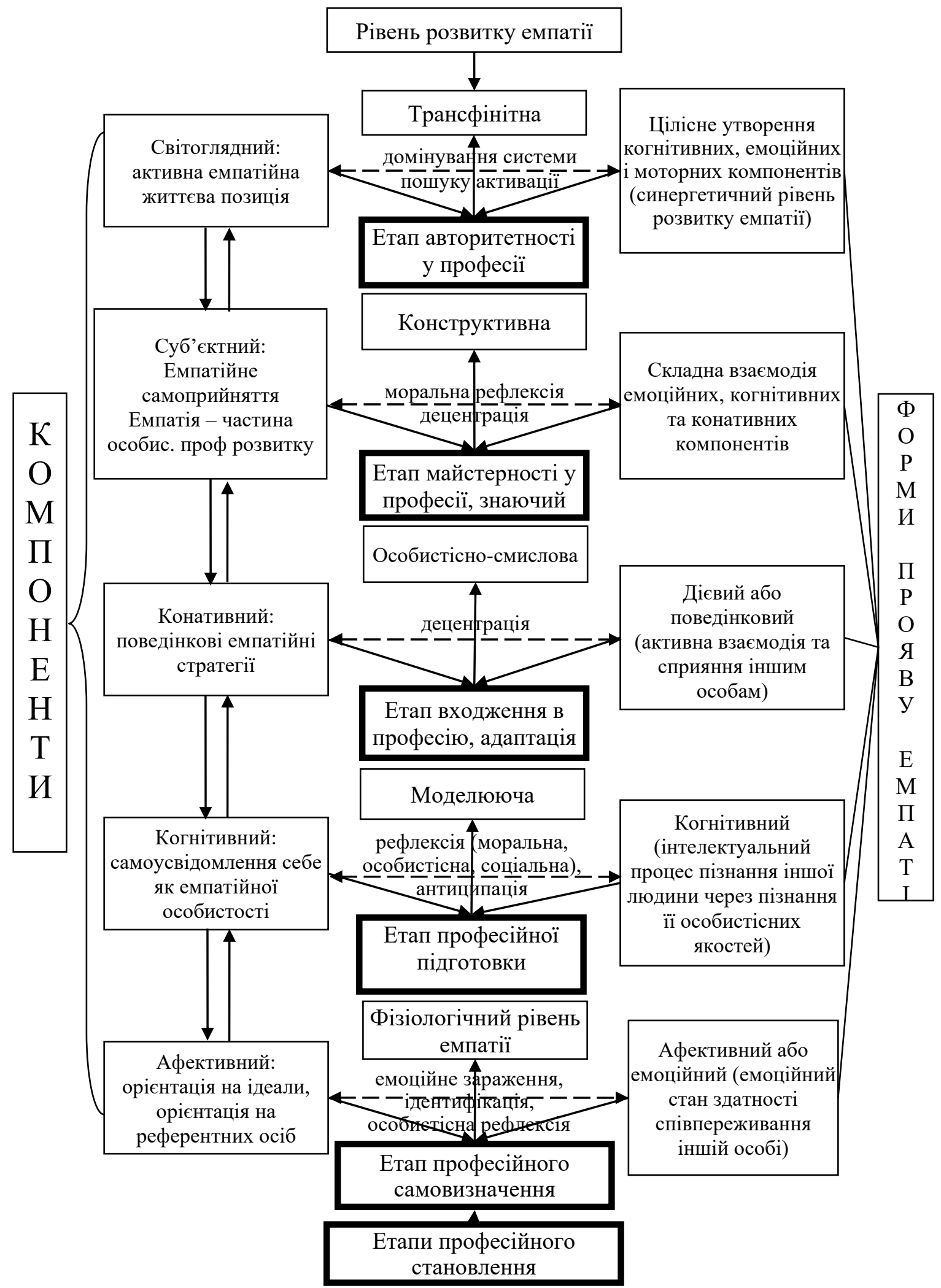

Рис. 1. Структурно-динамічна модель розвитку емпатї практичних психологів

Більшість дослідників емпатійних явищ виділяють співпереживання і співчуття, як основні форми емпатії, співпереживання, як переживання суб'єктом тотожних почуттів об'єкта та співчуття, як переживання суб'єктом інших почуттів з приводу почуттів суб'єкта. Л.П. Журавльова [8] 
вирізняе нижчу (натуральну) форму емпатії та вищі форми іï розвитку (особистісно-смислову, трансфінітну). Особистісно-смислова емпатія піддається довільній регуляції та розвивається у процесі соціалізації. Трансфінітна емпатія проявляється у формі надвчування, альтруїзму.

Висновки. Підсумовуючи, варто закцентувати увагу на тому, що на пізніх стадіях професійного становлення у практичного психолога замість готовності співчувати, допомагати будьякою ціною, з' являється так званий рівень «адекватної» емпатії, готовність розділити відповідальність за консультативний процес, допомагати іншим «не на шкоду собі». Компетентнісний підхід у професійній освіті ставить завдання розвитку емпатії як вміння та навички у фахівців допомагаючих професій. Це передбачає конкретизацію уявлень про емпатію, що дозволяс виявляти й оцінювати рівні іiі розвитку, показники поведінкових проявів, розробляти навчальні програми, спрямовані на іiі розвиток. У той же час концептуальне осмислення проблематики емпатії в психології в цілому характеризується багатозначністю, невизначеністю основних понять, еклектичністю підходів. Відсутні концепції емпатії, що дозволяють аналізувати багатоплановий, багаторівневий, системний характер емпатичних феноменів. У психології емпатії назрілим завданням $є$ розробка такого підходу, який забезпечив би плідну рефлексію «практики емпатії» в діяльності допомагаючих професіоналів і обгрунтування принципів розробки методів і прийомів їі розвитку.

\section{REFERENCES}

1. Bandura, A. (2000). Teoriya sotsialnogo naucheniya [Social learning theory]. Sankt-Peterburg [in Russian].

2. Berdyaev, N. A. (1931). O naznachenii cheloveka. Opyit paradoksalnoy etiki [About the appointment of a person. The experience of paradoxical ethics]. Parij [in Russian].

3. Bern, E. (1992). Transaktsionnyiy analiz i psihoterapiya [Transactional Analysis and Psychotherapy]. Sankt-Peterburg: Bratstvo [in Russian].

4. Viliuzhanina, T.A. (2006). Dynamika tsinnisno-smyslovoi sfery osobystosti v protsesi profesiinoho stanovlennia maibutnikh psykholohiv [Dynamics of the value-semantic sphere of personality in the process of professional development of future psychologists]. Extended abstract of Candidate's thesis. Kyiv [ in Ukrainian].

5. Gavrilova, T. P. (1975). Ponyatie empatii v zarubejnoy psihologii (Istoricheskiy obzor i sovremennyie problemyi) [The concept of empathy in foreign psychology (Historical review and modern problems)]. Voprosyi psihologii - Psychology issues, 2, 147-158 [in Russian].

6. Gornostay, P.P. (2018). Konsultivnaya psihologiya: Teoriya i praktika problemnogo podhoda [Counseling Psychology: Theory and Practice of the Problem Approach]. Kiev [in Russian].

7. Hupalovska, V.A. (2005). Profesiina samorealizatsiia yak chynnyk stanovlennia osobystosti zhinky [Professional self-realization as a factor in the formation of a woman's personality]. Extended abstract of Candidate's thesis. Kyiv [ in Ukrainian].

8. Zhuravlova, L.P. (2007). Psykholohiia empatii [Psychology of empathy]. Zhytomyr: ZhDU im. Ivana Franka [in Ukrainian].

9. Zeer, E.F. (2007). Psihologiya professionalnogo razvitiya [Psychology of professional development]. Moscow [in Russian].

10. Klimov, E.A. (1990). Kak vyibirat professiyu [How to choose a profession]. Moscow [in Russian].

11. Kokun, O.M. (2012). Psykholohiia profesiinoho stanovlennia suchasnoho fakhivtsia [Psychology of professional development of a modern specialist]. Kyiv: DP «Inform.-analit. Ahenstvo» [ in Ukrainian].

12. Maslou, A. (1999). Motivatsiya i lichnost [Motivation and personality]. Sankt-Peterburg: Evraziya [in Russian].

13. Markova, A.K. (1996). Psihologiya professionalizma [Psychology of professionalism]. Moscow [in Russian].

14. Mova, L.V. (2003). Psykholohichni osoblyvosti zabezpechennia osobystisnoi samorealizatsii maibutnikh psykholohiv u protsesi fakhovoi pidhotovky [Psychological features of personal support self-realization of future psychologists in the process of professional training]. Extended abstract of Candidate's thesis. Kyiv [ in Ukrainian].

15. Orlov, A.B. \& Hazanova, M. A. (1993). Fenomenyi empatii i kongruentnosti [The phenomena of empathy and congruence]. Voprosyi psihologii - Psychology issues, 4, 68-73. [in Russian].

16. Povarenkov, YU.P. (2005). Sistemogeneticheskaya kontseptsiya professionalnogo stanovleniya cheloveka [Systemogenetic concept of human professional development]. Moscow: Institut psihologii RAN [in Russian].

17. Poviakel, N.I. (1998). Profesiina refleksiia psykholoha-praktyka [Professional reflection of a psychologist-practitioner]. Praktychna psykholohiia ta sotsialna robota - Practical psychology and social work. 6-7, 3-6. [in Ukrainian].

18. Romanova, E.S. (1991). Psihologiya professionalnogo stanovleniya lichnosti [Psychology of professional personality formation]. Extended abstract of Doctor's thesis. Moscow [in Russian].

19. Stepanov, S.YU. \& Semenov, I.N. (1985). Psihologiya refleksii: problemyi issledovaniya [Psychology of Reflection: Research Problems]. Voprosyi psihologii - Psychology issues, 3. 31-40. [in Russian].

20. Surhund, N.A. (2004). Psykhodiahnostyka profesiinoi prydatnosti maibutnoho praktychnoho psykholoha [Psychodiagnostics of professional suitability of the future practical psychologist]. Extended abstract of Candidate's thesis. Kyiv [in Ukrainian].

21. Tolochek, V. A. (2005). Sovremennaya psihologiya truda [Modern labor psychology]. Piter [in Russian].

22. Merry T. Guide to the Person-Centered Approach. Loughton: Gale Centre Publications, 1990.

23. Rogers C. Client-centered therapy. Comprehensive Textbook on Psychiatry. 5 ed. / Kaplan H.I., Sadock B.J. (eds.) Baltimore Williams \& Wilkins, 1988. P. 3-40. 